\title{
UNIQUELY SINGAPORE: THE MANAGEMENT OF ISLAM IN A SMALL ISLAND REPUBLIC
}

\author{
Suzaina Kadir*
}

\begin{abstract}
This article explores the dynamics of Singapore's administration and management of its minority Muslim population. Singapore has developed a reputation of being highly interventionist in all aspects of its citizens' lives, including the private domain. Not surprisingly, there is a slew of legislation governing the religious beliefs and practices of its citizens, aimed primarily at maintaining religious and racial harmony. Islam and the Muslim minority, it can be argued, have been at the receiving end of tighter state management as compared to the other religious communities. This article traces the evolution of the state's administration of Islam in Singapore and explores the historical and contemporary reasoning behind such careful management of its Muslim citizens. It lays out the evolution of a Singapore model of accommodating and administering a religious/Muslim minority, and questions the sustainability and exportability of such a governance model.
\end{abstract}

\section{Introduction}

On 4 January 2002, Singaporeans witnessed what several news agencies described as "the most potent act of civil disobedience this tightly controlled nation had seen in years" when four seven-year-old schoolgirls defied the Ministry of Education's warning and attended the first day of school wearing the Muslim headscarf or tudung, as it is referred to in Malay. Local and foreign media carried scenes of the four girls clutching their fathers' hands as they walked into the school compound in a modified uniform. Fear and uncertainty registered on the girls' faces while the fathers looked 'defiant' and school officials watched uncomfortably. In interviews with local media one of the fathers admitted that his daughter was reluctant to attend school but insisted that "my religion is as important to me as education, [so] why do I have to choose between them?"2 The four schoolgirls were subsequently suspended from attending public school.

The incident represented the height of what is now referred to as the 'tudung controversy' in Singapore politics. It sparked intense discussions between

* Suzaina Kadir is Senior Lecturer at the Lee Kuan Yew School of Public Policy in Singapore. 
representatives of the Muslim community and the government. The Majlis Ugama Islam Singapura (MUIS, Islamic Religious Council of Singapore) was forced to issue a public statement to defuse tensions, pointing out that Islam did not require girls to cover their hair at such a young age. ${ }^{3}$ There were also heated debates on internet discussion groups, as well as protests from international non-governmental organisations. For example, KARAMAH, the Association of Muslim Women Lawyers for Human Rights, sent an official letter of protest to Singapore's ambassador to the United States. They insisted that the Singapore government abide by its constitutional guarantee to uphold the religious freedoms of its minority communities. ${ }^{4}$

In a country where any form of public performance and gathering requires a special police permit, such a public debate around the headscarf is especially striking. Singapore has prided itself of successfully managing a multi-ethnic and multi-religious population. The controversy therefore suggested a level of serious contention, previously undetected, involving the Muslim minority and the state. In order to better contextualise the 'tudung controversy', this article will examine the relationship between the Muslim community and the State in contemporary Singapore. It will explore how this relationship has evolved over time and what new arenas of contestation have emerged, and - more specifically - whether the tudung incident should be seen as an act of civil disobedience against a state infringing on the rights of its religious minorities. The article does not, however, address international issues as they have played out in Singapore.

The article situates these questions within a larger debate regarding the integration and adaptability of Muslims vis-à-vis the secular nation-state. While Muslims comprise a minority in Singapore, the city-state is not immune to larger tensions within the Muslim world, such as the wars in Afghanistan and Iraq, or the IsraeliPalestinian conflict. This debate is not new. Its history can be traced to the emergence of the modern nation-state. Europe's Reformation and the Enlightenment periods paved the way for the institutionalisation of a secular public realm of government and a private realm for religion. However, Islam never encountered something similar to Europe's Enlightenment and rather propagated a holistic conceptualisation of life, embracing politics, economics and society. For some this has meant the establishment of an 'Islamic state' in contrast to the secular nation-state. For others, it has meant the implementation of Islamic law and the establishment of an Islamic society within the framework of a modern state. Muslim scholars remain divided, however, on the position of Muslim minorities living within the territorial boundaries of a secular state. Specific to Southeast Asia, tensions between secularism and Islam are tied to the colonial experience and the nationalist struggles in the early twentieth century. In Indonesia and Malaya, Islam was an integral part of the anti-colonial struggle. However, the tensions between Islam, democracy, secularism and the nation-state remain unresolved in these countries today. 
Based predominantly on news reports, interviews with Muslim leaders and participant observations in dialogue sessions with select Islamic organisations, as well as between these organisations and the state, this article begins with a look at Islam and the Muslim community in Singapore, with close attention to the ethnic dimension. While no careful study has been done so far to measure the levels of religiosity within the Muslim community, this writer argues that modernisation, Islamisation and globalisation are producing new tensions within the community, creating new or changing existing horizontal linkages between community organisations. The article proceeds to examine the vertical linkages between the community and the state through examining the administration of Islam and considers several new arenas of tension in the evolving relationship between the two parties. These horizontal and vertical contestations constitute the increasingly complex sets of linkages between Muslim minority communities and the secular state.

\section{Malays and Muslims in Singapore}

Muslims constitute a politically significant religious minority in Singapore. They make up 14.9 per cent of a total population of 3.26 million. ${ }^{5}$ This is compounded by the fact that some 99.6 per cent of the Malays are Muslims - essentially, almost all Malays are Muslims. The rest of the Muslim community is made up of Singaporeans of Arab descent, a segment with South Asian descent and a small number of Chinese and Eurasian converts. This conflation of Malay ethnicity and Islamic identity creates a unique and particular dynamic to the issue of Muslims in Singapore. It leads to a perception of homogeneity in addressing Muslims, and questions of integration/accommodation involve inevitably both religious and ethnic dimensions.

There is an additional regional dimension. Singapore's immediate neighbours, Indonesia and Malaysia, comprise populations which are overwhelmingly Malay (in the case of Malaysia) and Muslim. Muslims make up some 87 per cent of Indonesia's population of around 210 million people. In Malaysia, Malays and Muslims make up about 60 per cent of the population. Hence while Malays/Muslims are a minority in Singapore, they nevertheless constitute a majority within the region. The Singapore government is acutely aware of this. In 2000, then Deputy Prime Minister Lee Hsien Loong admitted the state's concerns regarding the 'loyalty' of Malays/Muslims in the event of a war against fellow Malays/Muslims in the region.

In spite of the conflation of the Islamic religion with Malay ethnic identity, much of the scholarship on ethnicity in Singapore has focused on the issue of Malays rather than on Islam. ${ }^{6}$ The socio-economic status of Malays has been a longstanding matter of concern in the management of multi-ethnicity. For example, data shows that Malay-Muslims continue to lag behind Chinese and Indians in education and 
income levels. Data from Gallup International showed that there are only 11 per cent of Malays/Muslims earning more than US\$2,000 a month compared to 30.8 per cent of Chinese and 18.9 per cent of Indians. ${ }^{7}$ Only 28 per cent of the Malays gained admission to post-secondary educational institutions and polytechnics as compared to 68 per cent of Chinese and 37 per cent of Indians. ${ }^{8}$ At the tertiary level only 4.2 per cent of Malay-Muslims were admitted to universities in 1999. This has led to allegations that Malays/Muslims in Singapore are a marginalised community much like other Muslim minorities elsewhere in Southeast Asia. ${ }^{9}$

Singapore government officials have acknowledged the disparity and - like the academics who adopt the ethnic-linguistic approach - state policies have focused almost exclusively on helping the Malay community to improve their economic status. In 1980, the government established Majlis Pendidikan Anak-Anak Islam (MENDAKI, Council on Education for Muslim Children), a self-help organisation that would provide free tuition classes for Malay students who could not afford private tutors. It also branched into exploring economic opportunities for Malays and providing welfare services for poorer families. Other government aided organisations, such as the Association of Malay-Muslim Professionals (AMP), also focused on improving the educational standards and socio-economic status of Malays. As a result, the educational level of the Malays has improved over time. ${ }^{10}$

The contemporary conflation of Islam and Malay is obviously a historical phenomenon. It has its beginning with the arrival and spread of Islam in Southeast Asia. Islam arrived in Southeast Asia via Arab and Indian traders who plied the Indian Ocean trade routes. Mass conversions of indigenous communities occurred around the fourteenth century when the rulers of various coastal kingdoms embraced Islam. ${ }^{11}$ Subsequently, Islam spread further inland, mixing with and adapting to the existing cultures and traditions. Gradually, a Malay-Muslim community - the amalgamation of Islam with 'Malayness' - emerged, ${ }^{12}$ and over time Islam came to be identified with being a 'Malay'.

At the beginning of the nineteenth century, the Muslim community in Singapore could be divided into two broad categories of migrants: those from within the Southeast Asian region, such as Java, Sumatra and Riau; and those from outside, notably South Asia and the Arab lands. ${ }^{13}$ The migrant character of the Muslim society of those days meant that no indigenous traditional authority governed or represented Islam. Hence, as Siddique has argued, "because of the ethnic heterogeneity of the Singapore Muslim population, one had, for at least a better part of the 19th century, not a Muslim community, but a number of Muslim communities [...] reinforced from within by the preservation of linguistic barriers, place of origin, occupational specialisations, diverse economic and educational levels". ${ }^{14}$

The situation began to change only towards the end of the nineteenth century, as the British colonial administration became more direct and urbanisation started 
to break down existing barriers between the different Muslim communities. In 1877, representatives from the Muslim communities approached the British for an improvement of the administration of Muslim marriages. This resulted in the enactment of the Mohammedan Marriage Ordinance three years later. Muslims also sought British help to coordinate hajj (pilgrimage to Mecca) activities and manage religious funds. In 1906, the Muslim Endowments Board was established and finally, in 1915, the Muhammedan Advisory Board was set up, providing an official avenue for Muslim representatives to negotiate with the British colonial administration. These developments paved the way for Muslim representation in Singapore's colonial setup, but more importantly, it began to centralise religious administration and allowed for the evolution of a specific religious consciousness among the different Muslim communities. The emerging Muslim elite emphasised the implementation and practice of the shari ${ }^{\prime} a h$ as anchoring religious identity and transcending ethno-linguistic differences. ${ }^{15}$ Possibly influenced by the current modernist thinking from the Middle East seeking to 'purify' Muslim communities from traditional practices perceived as 'non-Islamic', these Muslim elites increasingly turned to the sharì $a h$.

The British, in turn, aided the emerging Malay-Muslim identity among Singapore Muslims by de facto recognising the Malays as the quasi representatives of Islam in Singapore. ${ }^{16}$ The British had previously recognised the Malay sultans as the guardian of Islam on their protectorates on the Malay Peninsula and, therefore, did the same for Singapore. Hence, for example, in 1921 the Muslim Institute in Singapore sought two seats - one for a Malay and the other for a non-Malay Muslim - on the Legislative Council. After some pressure, the British agreed to the appointment of a Malay, Mohd Eunos Abdullah, to the Municipal Council, but denied the appointment of an Arab Muslim, despite strong lobbying by the Muslim and Arab Associations.

The institutionalisation of Islamic administration in Singapore intensified and accelerated after the brutal Japanese Occupation, culminating with Muslim Ordinance in 1957 and the setting up of the Shari 'ah Court and the Registry of Muslim Marriages (ROMM) in 1958. After Singapore's independence, the Administration of Muslim Law Act (AMLA) was enacted, allowing for the establishment of the earlier mentioned Islamic Religious Council, MUIS, in 1968. Subsequently, MUIS would come to represent a culmination of the fusion of Malay and Muslim identities in Singapore, a point to which we shall return in the next section. MUIS sought a central role in shaping the Muslim community, since it became to the government the sole legitimate representation for Islam in the island republic. The centralisation of administration thus played a pivotal role in moulding a religious identity that sought to transcend the ethno-linguistic divides among Muslims in 
Singapore. The religious consciousness that emerged fused Malay and Islamic identities together and leant heavily towards sharī $a h$-related issues. ${ }^{17}$

The global Islamic revivalism of the 1960s and 1970s pushed for Islam to be the dominant, if not exclusive, identity for its adherents, propagating the notion of a transnational Muslim ummah as an integral part of Muslim identity ${ }^{18}$ and pushing for a comprehensive conceptualisation of Islam as a way of life and an anchor for economics, politics, state and society. This has had a significant impact on the continuing development of the Malay-Muslim religious consciousness in Singapore. This was seen in the increasingly public manifestations of a stricter Muslim identity. By the 1990s, for instance, a Malay-Muslim woman's dress-code tended to involve the covering of the head, in contrast to the portrayal of Malay-Muslim women in media images during the $1950 \mathrm{~s} .{ }^{19}$ Similarly, more Muslims adhered to their Islamic obligations, and there was a stricter conformity to dietary requirements. ${ }^{20}$ Growing Islamic consciousness can also be linked to the increasing number of Muslim parents opting to enrol their children in madrasahs or Islamic religious schools. Data from MUIS showed that the number of applications to madrasahs jumped from 824 in 1994 to 1,354 in 2000. A Gallup survey of 1,000 households in 2000 which asked respondents to rank their forms of identification in terms of ethnicity, religion, and neighbourhood, found that Malays identified chiefly with religion - in contrast to Chinese who identify with ethnicity and neighbourhood. ${ }^{21}$ The finding, therefore, supports the observation of a general trend towards increasing identification with religious symbols associated with Islam.

However, growing religious consciousness among Muslims in Singapore should not lead to an erroneous assumption of homogeneity brought about by global Islamic revivalism. In Singapore, as elsewhere in the Islamic world, religious revivalism has not produced a homogeneous Islamic identity. While revivalist thought reinforced the role of the traditional Islamic clerics - the 'ulama ' - access to education and exposure to different Muslim communities have produced emerging centres of religious authority. 'Cyber- 'ulam $\bar{a}$ " and younger Western educated Islamic scholars have become more vocal in their debates with the traditional 'ulama ', especially over the latter's literal interpretations of the Qur'ān. Even in Iran - usually considered the 'theocracy' par excellence - there are serious challenges to the dominant discourse of the clerics. Several studies have shown how revivalist ideology coupled with modernisation, urbanisation, and globalisation has intensified contestations for meaning and representation within Islam. ${ }^{22}$

\section{Growing Pluralism and Muslims in Singapore}

In Singapore, while historical developments have produced a conflation between Islamic and Malay identities, the heterogeneity among Muslims is likely to increase. 
There exist, for instance, different levels and layers of religiosity among the population which, in turn, are linked to different educational and income levels. One can infer this from the increasing trend among parents with post-secondary or even tertiary education to enrol their children in Islamic religious schools. In addition, like in other parts of the Muslim world, modernisation and globalisation are producing different readings and understandings about Islam and its practices among the different generations of Islamic scholars.

The first generation of Singaporean 'ulama ' was educated in Islamic schools in the region and steeped with knowledge of the $\operatorname{sharī~}^{-} a h$, but they also embraced Sufi thought and retained an accommodating attitude towards local traditions and customs and British colonial administrators. They taught in the various madrasahs and played an important role in making Singapore a regional hub for the teaching of the Arabic language in Southeast Asia. ${ }^{23}$ An example of this first generation of 'ulamā' would be Ustaz Burhanuddin al-Helmy who taught at Singapore's Madrasah Aljunied in the 1950s. By the end of the 1960s, a second generation of Islamic scholars emerged out of the few students from this Madrasah who gained entry to Al-Azhar University in Egypt. They were exposed to the global revivalism thinking that was sweeping through the Middle East in the 1970s, which produced a somewhat more rigid interpretation of Islam and the shar ' $a h$. The second generation pushed for the creation of an Islamic society. Many of them focused on increasing religious consciousness among Muslims rather than engage with the state on matters of society and politics. For example, the Singapore Islamic Scholars and Religious Teachers Association (PERGAS) under the leadership of Ustaz Ali consciously chose not to engage the state on the issues of morality or society and focused instead on educating the population on becoming better Muslims and eradication of non-Islamic practices and beliefs. ${ }^{24}$

The educational background of the newly emerging third generation of Islamic scholars is more diverse. Muhammad Haniff Hassan divided them into three groups - those who were educated wholly in local madrasahs, those with a mixture of madrasah and government secular education and those who underwent the traditional method of studying with the first and second generation 'ulama $\bar{a}$ '. ${ }^{25}$ In addition, an increasing number of 'ulama ' were able to obtain a degree from other universities in the Middle East, including the University of Media in the 1980s. ${ }^{26}$ Medina trained Islamic scholars displayed a staunchly shar ‘̄ ah-oriented mindset and were determined to push society towards a proper implementation of Islamic law in everyday life. Unlike the second generation scholars, however, the Medinaeducated 'ulam $\bar{a}$ ' believed that engagement with society and state was necessary to protect the moral being of Muslims. ${ }^{27}$

Beyond the 'ulamā', education and technological advancements have also enabled ordinary Muslims to access and reinterpret the religion for themselves. Using new 
media of communication, such as the internet, many Western-educated Muslim scholars challenge the traditional authority of the 'ulamā'. In countries like Egypt, Iran, Malaysia and Indonesia, for example, movements calling for a liberal or even secular interpretation of the Qur'ān have emerged vis-à-vis more sharì 'ah-minded approaches. These movements, however, have not gained significant ground and are still in their infancy in Singapore as compared to other parts of the Muslim world. Nevertheless, there has been a greater openness to these liberal thinkers. In 2003, MUIS invited Muslim scholars like Ali Asghar Engineer, Tariq Ramadan, Abdullah An-Naim and Ulil Abshor Abdillah to speak to the Muslim public. These talks were met with high levels of interest among the younger, well-educated Muslims.

The President of MUIS, Mr Alami Musa explained that Muslims in Singapore had gone through three development phases. He described the first phase as 'traditionalist Islam' where religious fused with existing cultural traditions. Subsequently Muslims underwent a 'revivalist phase' where Muslims sought a return to a purified version of Islam as a way of life. He added that Muslims in Singapore were now embarking on a 'progressive phase' in which they were exploring their position within a secular state. ${ }^{28}$ These different phases have produced a plurality of interpretations and perspectives among Muslims towards the religion. He added that the challenge for MUIS was to create an environment of tolerance for divergent views and ideas among Muslims. ${ }^{29}$

Dale Eickelman and James Piscatori ${ }^{30}$ have pointed out that the growing plurality of voices would inevitably result in a horizontal contestation for religious authority and representation among the Muslim communities around the world. They referred specifically to the emergence of a new religious elite that sought to challenge the traditional authority of the 'ulama'. In Singapore, there are new tensions emerging over a range of issues pertaining to Islamic identity within a secular nation-state. They include differences of opinion regarding the role of Islamic education, the use of the Muslim headscarf in public schools, and secularism. More importantly, these horizontal contestations over meanings within the Muslim community have spilt over into vertical tensions with the state over the legitimate representation of the Muslim community. However, before we can explore this nexus a brief look at the administration of Islam in post-independence Singapore is necessary.

\section{The Administration of Islam in Singapore}

Singapore is a secular state. The Constitution upholds the right of groups to adhere to their religious faiths but enshrines a separation of religion and state. Experiences with religious riots, including the 1964 riots during the Prophet Muhammad's birthday celebrations, have led to strong controls on religious activities. For example, while all religious groups are granted space to engage in their practices, 
open and aggressive proselytising is not allowed. Additionally, a Maintenance of Religious Harmony Act was enacted in the late 1980s authorising the state to "take action against any religious group or institution that carried out subversive activities under the guise of practising religious belief' following the involvement of church groups in a perceived 'Communist conspiracy'. However, it is important to note that the state does not ban or bar religious activities. Indeed, it could be argued that the state encourages the development of religious moral codes for its respective citizen-communities but insists that religious identities be kept out of politics. The idea of secularism as propagated by the state is thus more complex than simply privatisation of religion. This is reflected in its administration of Islam.

As discussed earlier the framework for the administration of Islam was laid out during the later part of the British colonial administration when the Muslim elite negotiated for representation in state, pushed for greater coordination of Islamic practices and the implementation of the shari ${ }^{\prime} a h$ as customary code alongside civil law, culminating in the enactment of the Muslim Ordinance of 1957. In 1965 the Administration of Muslim Law Act (AMLA) was introduced in the newly independent Singapore parliament to reinforce the provisions already in the Muslim Ordinance and synchronise the management of Muslim affairs such as collection of the zakät (islam's obligatory 'alms tax'), administration of mosques, management of waqf (an inalienable religious endowment in Islamic law, typically denoting a building or plot of land for Muslim religious or charitable purposes; in Malay known as wakaf) land and the coordination of hajj activities. The AMLA also called for the creation of a statutory board that could advise the government on matters pertaining to the Muslim community, leading to the establishment of MUIS in 1968. MUIS constitutes an executive-president who was appointed by the President of the Republic of Singapore on the recommendation of the Prime Minister and a list of nominees from the different Muslim organisations in Singapore. In addition, the office of muftī, or the country's chief expounder of Islamic law, was also created to preside over the Fatwa Committee, with the responsibility of issuing religious rulings pertaining to Islamic law.

With the establishment of MUIS, Muslims in Singapore encountered a religious bureaucracy that sought to administer and manage the community. It has a central role in the collection of zakät fitrah (an additional charity to be paid once a year), the administration of all wakaf land by the Muslim Endowments Board and centralisation of the annual hajj pilgrimage to Mecca; from 1975 onwards, all pilgrims had to register with MUIS before obtaining their relevant visas and could only perform the hajj through MUIS-approved vendors. The centralisation of religious administration was also evident in the role that MUIS would come to play in mosque management.

Prior to Singapore's independence, individual mosques were constructed and maintained by the local Muslim populations living within their respective vicinities. 
MUIS acquired responsibility for managing about 90 existing village mosques. ${ }^{31}$ In the immediate post-independence period, however, the government embarked on a massive public housing development project. This meant that many Muslims, along with the rest of the population, were re-settled in modern apartment blocks. Muslims were thus cut off from their village mosques, which were also likely to be demolished to make way for new development projects, including large public housing estates. In the 1970 s, the decision was made to build large centralised mosques in each housing estate. However, there were concerns over whether sufficient funds could be raised to build and maintain those large mosques. MUIS emerged as a key player in ensuring that the minority Muslim communities were not deprived of their mosques when it pushed for the establishment of a Mosque Building Fund (MBF). The MBF sought to utilise a small portion of the compulsory social security fund the Central Provident Fund (CPF) of Muslim citizens to help in the building and maintenance of the mosques. The government agreed to the establishment of the MBF in 1975.

The MBF is wholly administered by MUIS and has been crucial in the massive construction of 'new generation' mosques throughout Singapore. It was only through the MBF that sufficient funds were raised to build these large centralised mosques to replace smaller kampong (or rural) mosques destroyed in the urban redevelopment plan. Between 1975 and 1980, six new mosques were built amounting to a total cost of $\mathrm{S} \$ 10,985,580$. Each mosque is capable of accommodating between 1,000 and 2,000 people and is equipped to provide a wide range of activities. Consequently, from the 1980s onwards mosques flourished as centres of activity for Muslims. These new generation mosques provided kindergartens, religious classes, pilgrimage classes, Arabic language courses, remedial tuition classes and even family counselling. The former president of MUIS, Haji Maarof Salleh, proudly proclaimed that mosque building and management had been among the most successful responsibilities undertaken by MUIS to date. ${ }^{32} \mathrm{He}$ added that this project was so successful that it had led to complains from the government that Muslims were not making use of facilities provided by the Community Centres (CCs) in the public housing estates. ${ }^{33}$

AMLA has provided for the establishment of a centralised religious bureaucracy, MUIS, to administer Islam in Singapore. This has led Siddique to point out that "few foresaw the hegemonic role which MUIS would play in the development of the Muslim community in the 1970s and 1980s" ${ }^{34}$ However, the writer of these lines would argue that the state's centralised administration of Muslims in Singapore has not always been smooth. While the AMLA has facilitated the administration of shari 'ah courts and the Registry of Muslim Marriages and enabled MUIS to take over select Islamic activities including mosque building and maintenance, centralised control over other autonomous Islamic institutions was more difficult. Many of these institutions had been in existence prior to the establishment of 
MUIS. For example the position of the 'ulamā' is not easily controlled by MUIS. While MUIS's approval is necessary for the nominees to mosque management committees, the 'ulama"s authority within the mosque cannot be easily challenged. ${ }^{35}$ An individual Muslim cleric can still deliver his own sermons over and above those of the text provided by MUIS although most would read the MUIS-prescribed texts first. The uneasy relationship between MUIS and PERGAS is a testimony to this. We shall return to this point later.

More recently, engagements between the state and the Muslim community over Islamic education in Singapore has pointed to the difficulties of administering Islam through a centralised bureaucracy. In 1999, then Prime Minister Goh Chok Tong voiced concerns about the number of madrasah students who were dropping out without completing their lower secondary education. ${ }^{36}$ The speech and subsequent announcement that the Ministry of Education would make elementary school education compulsory for all Singaporeans sparked a storm of discussions within the Muslim community regarding the future of Islamic education in Singapore. In the process, it became clear that MUIS had not been able to extend its administration over the madrasahs in Singapore. MUIS officials I interviewed admitted that they had very little power and authority over these schools. ${ }^{37}$ They attributed this to the fact that the madrasahs had been in existence since the late nineteenth and early twentieth centuries. Furthermore, the madrasahs came under the purview of the Ministry of Education as 'private schools' whose authority superseded that of MUIS. Therefore, the madrasahs and their religious teachers enjoyed substantial autonomy in the administration, curriculum and teaching within these schools.

Additionally, there are various religious organisations/bodies that are relatively autonomous from MUIS. Many of these organisations existed prior to Singapore's independence, and while MUIS oversees these associations, they retain their institutional independence. Examples include PERGAS, the Singapore Dakwah Movement (PERDAUS), and the Muslim Missionary Society of Singapore (Jami'yah). PERGAS was registered as an association in 1957, while Jami'yah is the oldest Islamic organisation in Singapore, having been established in 1932. Both associations had provided submissions during the drafting of the AMLA in 1966. Disagreements between MUIS and these associations have occurred in the past but more often than not such debates took place behind closed doors. For example, there were disagreements between MUIS and Indian-Muslim associations over the use of the Muslim Endowment Fund in the 1970s. There had also been disagreements between MUIS and Jami'yah over dakwah (proselytising) activities.

There have been rather public demonstrations of disagreements between MUIS and these Islamic bodies more recently. This writer argues that this has been a reflection of the new tensions over representation of Islamic authority in Singapore. For example, in the run-up to the war in Iraq, four Islamic organisations in Singapore 
came out to issue a joint press statement objecting to the US move. They were PERGAS, PERDAUS, Muhammadiyah and the Centre for Contemporary Islamic Studies (CCIS). MUIS had registered discomfort but stopped far short of making a statement against the US-led war. In several discussions with cabinet ministers and MUIS officials prior to and during the initial few days of the US-led war, representatives from these organisations had also voiced their displeasure at Singapore's firm support for the US position. They made clear that even if MUIS could not come out publicly against the war, they - as representatives of the Muslim community should be given the right and space to voice their objections.

\section{Emerging Arenas of Contestation Between State and Muslims in Singapore}

What we have seen is, therefore, the emergence of horizontal and vertical contestations for meanings and representation of Islam in contemporary Singapore. These emerging pluralities of meanings, however, are confronted with the push for the centralisation of religious administration by the state. In other words, while new ideas and interpretations continue to evolve from within the Muslim communities in Singapore, the space within which these contestations can take place appears to be shrinking. This is producing new arenas of tension between the state, often represented by MUIS, and groups within the Muslim community. We would highlight here several issue areas that reflect the growing tensions over legitimate representation of Islamic authority in Singapore. The 'tudung controversy' mentioned at the beginning of this article must be taken alongside these other areas of contestations.

However, we should begin briefly with a discussion of the Jemaah Islamiyah threat to Singapore. The discovery of a regional terrorist network, operating and being coordinated from within Singapore, raised the question of potential conflict between Muslims and the state to high prominence. If there was to be growing tension and potential for conflict between a secular state and an increasingly religious minority population, the threat would be the best evidence of this. However, we should make the case here that the network itself is fairly disconnected to these developments within the Muslim community in the sense that it does not reflect a conflict between a disenfranchised religious minority community against a repressive state. Yet, the existence of Jemaah Islamiyah suggests the growth of radical perspectives on Islam and a potential arena of conflict between its ideology and that of a secular state.

\section{Jemaah Islamiyah}

Between December 2001 and August 2002, Singapore's Internal Security Department (ISD) arrested 34 Muslim men for planning bomb attacks throughout Singapore. 
These men were leaders and members of the Jemaah Islamiyah (JI) regional terrorist cells linking Indonesia, Malaysia, and Singapore. Their aim was to create a dawlah islämiyyah (Islamic state) in the region through the use of violence. ${ }^{38} \mathrm{JI}$ is also linked to the bombings in Bali in October 2002 and the more recent Mariott Hotel bombing in the centre of the Indonesian capital of Jakarta.

The discovery of the plot proved shocking for the government as well as the citizens of Singapore. It reinforced the emerging dominant discourse of a growing Islamic consciousness among Muslims and suggested for the first time a link with religious extremism. To put it another way, it reinforced the notion of an increasingly homogeneous fundamentalist Islam growing on Singapore soil. It raised the question of incompatibility between Islam and secularism as much as old questions regarding the marginalisation of minority communities by Singapore's predominantly non-Malay and non-Muslim state.

The White Paper on the JI revealed that the arrested men were relatively educated and with jobs. It stated that "these men were not ignorant, destitute or disenfranchised", but appeared to regard "religion as the most important personal value". ${ }^{39}$ The document did point out that the men tended to shun "mainstream" religious classes or gatherings and were focused on creating an Islamic state in the region through jihad.

While a case can be made that the men were not economically deprived, the alienation of these men vis-à-vis the secular, capitalist state can factor into why there was involvement in such activities. There was evidence that the men had received education and training in Afghanistan and Pakistan prior to joining JI activities. Several reports suggested that trips to Pakistan exposed the soon-to-be regional leaders of JI to a more militant understanding of their religion. Upon their return the men recruited followers. The growing sense of frustration and alienation vis-à-vis the larger community and state among fellow Muslims led the few to be attracted to the JI ideology. Nevertheless, further research is necessary in explaining the link between religiosity and violent action of the kind planned by the JI members.

It is also important to point out that the reaction of the Muslim community towards the arrest and imprisonment of the JI members was fairly uniform. From shocked disbelief that such a network had evolved in Singapore, Muslim organisations came out in support of the arrests. All condemned the planned actions of the JI members and pointed out that such actions were not Islamic. Most felt that JI members had been led astray by external or foreign elements. Hence the focus turned to erroneous teachings in Islam with calls for a tightening of religious teaching. ${ }^{40}$ In many ways, JI quickly became a non-issue among Muslims in Singapore. The primary concern for many was how it would adversely affect the state's perception towards the community, including concerns about the labelling of Muslims into categories such as 'radical', 'moderate' and 'liberal'. 
The concern that there are efforts on the part of the state to further centralise and tighten control over the community vis-à-vis a religious bureaucracy and through its security agencies is real. For example, there are efforts to restructure MUIS so that the agency can better administer on matters pertaining to Islamic education and mosque development. For example, MUIS has finally been given additional authority to administer and develop the madrasahs in Singapore. Previously, the Ministry madrasahs remained under the purview of the Minister of Education. MUIS has also announced its intention to monitor mosques and madrasahs closely to prevent deviant teachings from being circulated. It has also reinforced a registry of Muslim or religious teachers. In light of the emerging tensions between MUIS and the Muslim community over legitimate representation of authority, such a move may in fact worsen the situation. It is to these emerging tensions that we now turn. They are over

- Islamic education,

- the Islamic headscarf,

- the issue of secularism and Islam, and

- alternative Muslim representation.

\section{The madrasah issue}

There are six full-time Islamic schools or madrasahs in Singapore. ${ }^{41}$ These madrasahs predate Singapore's political independence. After independence, madrasah education grew increasingly less popular as Malay-Muslim parents opted to send their children to national schools. However, in the mid 1980s, a growing number of parents opted to send their children, in particular young girls, to the madrasah. Government officials expressed their concern about this trend in August 1999. This sparked off heated discussions within the Muslim community and between the representatives of the madrasah and the government. Much of the debate occurred within the (now inactive) PERGAS website, CyberUmmah, with accusations that the state was intent on eliminating the last bastion of autonomous Islamic activity in Singapore.

When the government announced its intention to introduce Compulsory Education (CE) for all children from ages six to ten, PERGAS was compelled to issue a stern warning that it would not allow any effort to undermine or shut down Islamic education in Singapore. ${ }^{42}$ This caught many by surprise. For the first time it indicated willingness to confront the state openly. PERGAS officials explained that they had little choice but to express their views directly with the government on the issue. ${ }^{43}$ Meanwhile, others from outside the community of 'ulama' 'argued that if public schools allowed Muslims to adhere to Islamic practices, including the headscarf 
for women and scheduled prayer times, then madrasah education would be less attractive. Yet, others agreed with the government position that the madrasahs were not performing up to the mark and called for greater coordination of madrasah curricula and teacher training by MUIS. ${ }^{44}$

The madrasah debate appeared to have opened a Pandora's box on the struggle for meaning and representation within Islam and in the relationship between the Muslim community and the state. Government officials seemed surprised by the emotional responses from the 'ulama' 'community while the debates clearly showed that Muslims themselves were quite divided on the issues. In the end, the government appeared to have backed off and exempted students enrolled in the six full-time madrasahs from compulsory education in a public school. The state insisted however that the 'ulama' 'madrasahs would have to prepare their students for the Primary School Leaving Certification Examination and that it had the right to review the performance of these students at the end of the six years.

\section{The 'tudung' issue}

In spite of the publicity, the controversy over the Muslim headscarf did not suddenly emerge in 2003. Requests from parents for public schools to allow their daughters to wear the headscarf had been on the increase since the early 1990s. ${ }^{45}$ There were already instances when certain schools would allow female Muslim students to cover their head and wear a school uniform with longer sleeves and lengthier skirts. The issue was often raised at dialogue sessions between Muslim groups and government agencies. For example, in 2000, the issue was raised in a dialogue with then Prime Minister Goh Chok Tong, with rather passionate appeals for the government to allow the wearing of the headscarf so as to counter the increasing number of parents sending their children to a madrasah. This culminated with the public display of disagreement with the official policy on 2 January 2003 and the suspension of four young girls from primary school.

Following the incident, MUIS issued a public statement asserting that the religion of Islam did not require young girls to cover their heads ${ }^{46}$ It further stated that Islam prized education over the issue of awrah (in Malay: aurat; parts of the body that are permissible to be shown publicly) if a choice had to be made. This position, however, was not accepted by the 'ulama' '. The next day, PERGAS issued a statement maintaining that hijāb ('modest' covering for women) was compulsory and that "it is the responsibility of every individual Muslim to strive as best he/ she can to remove whatever causes which obstruct the fulfilment of one's religious duties". They implored the Muslim community to do their part in "finding a way such that our children can be permitted to don the modest attire as required by Islam when they are in school". ${ }^{47}$ 
While there had been no incidences of female Muslim students being barred from school since 2004, the 'tudung issue' is unlikely to disappear. Muslims were placated when then Prime Minister Goh Chok Tong announced the possibility of female students being allowed to wear the Muslim headscarf in the future. Muslim leaders interviewed by this writer, including the ones in PERGAS, were confident that if dialogue with the state on the issue was kept open and consistent, the government would ultimately relent on allowing the Muslim dresscode to become institutionalised. MUIS officials have found themselves in a tight spot in refusing to refute the claim of the 'ulama' ' on the issue. Discussions have not, for example, focused on the validity of the "ulama'"s claim but rather on strategies for negotiation with the state.

\section{Islam and secularism}

The president of MUIS, Alami Musa, acknowledged that there has been an emerging perception of tensions developing between Islam and secularism in Singapore. ${ }^{48} \mathrm{He}$ tied this to his observation that a progressive brand has been developing within the Muslim community, seeking an understanding of their position vis-à-vis a secular nation-state, as more and more Muslims come to grips with what it means to live as a Muslim minority in a secular state. This involves having a sphere for Islamic beliefs and practices without contradicting the basis of a secular state. Hence Muslims would reject secularism if it were an ideology that negates the position of religion but would have no problem with a secular state that respects the basic religious beliefs of its citizens, which is already constitutionally guaranteed.

Alami Musa's comments came after an 'ulamā' congress organised by PERGAS issued a statement regarding secularism and Islam in 2003. At this congress, 'ulam $\bar{a}$ ' deliberated on a range of issues including the labelling of Muslims as moderates and radicals, as well as future challenges facing Muslim communities around the world. The congress was not open to the public but a local Malay newspaper report stated that PERGAS 'ulamā' had endorsed the need for Singaporean Muslims to adapt themselves to a secular environment. ${ }^{49}$ PERGAS replied with another strongly worded statement denying that such a position was taken at the congress. ${ }^{50}$ In its statement, the president of PERGAS, Ustaz Hasbi, explained that Muslims could only accept a secular state if it meant that the state would remain neutral vis-à-vis religious groups in society. He reiterated that Islam was a comprehensive way of life and did not distinguish between the public and private spheres.

The issue of how Muslims should accommodate to a secular environment was actively discussed at the 2003 congress of 'ulamā'; they were cognisant of the inherent tensions. For example, the younger, university trained 'ulam $\bar{a}$ ' in particular were concerned about addressing the temptations facing Muslim youth, including basic questions regarding drinking alcohol, abortion and pre-marital sex. There was clear recognition that the globalised and westernised nature of Singapore society 
would seriously challenge Muslims and their faith. They felt it their responsibility to serve as the moral anchor for Muslim society since, as a Muslim cleric explained, "MUIS could not do it". When asked why, one of them explained that since "MUIS is a statutory board they must serve the interests of the state. It is our responsibility to serve the interest of the Muslim community."

Tensions between Islam and secularism are likely to persist. Already on 12 June 2004, PERGAS issued a press statement declaring their objections to government plans to turn Sentosa Island into a Las Vegas-like casino strip on grounds that gambling is immoral and would encourage other immoral activities. Sentosa is a small island of the southern tip of Singapore and had served as a tourist and recreational destination for some years. However, dwindling visitor arrivals prompted discussions about making the island a casino so as to generate economic activities and attract the tourist dollar. Dialogue sessions between government and the public to gather feedback on plans have only just started. It is clear that a new generation of 'ulama' ' is taking a proactive role in protecting the community from what they perceive as the onslaught of secularism.

\section{Alternative Muslim leadership}

At the tenth anniversary of the Association of Malay-Muslim Professionals (AMP) in 2000, the organisation proposed a multipronged approach towards the betterment of the Malay-Muslim community. AMP was formed in 1990 as an alternative voice to the government self-help group, MENDAKI. In its early years, AMP concentrated its activities on the educational economic advancement of the Malay community. Like MENDAKI, AMP conducted remedial classes, provided social welfare services for poor Malay families and ran enrichment classes for Malay children. However, in 2000 it developed an interest in managing growing Islamic consciousness among Malay-Muslims in Singapore..$^{52}$ The organisation proposed the development of the mosques and argued for the need to harness the leadership potential of religious leaders in helping the community move forward. They wanted a public role for Islam.

The state's reaction was to reject the AMP proposals for alternative Muslim leadership to Malay Members of Parliament as efforts at undermining the latter's legitimacy. The Prime Minister's Office issued a press statement declaring that if AMP wanted to propose alternative leadership for Malays they should form a political party and contest the general elections. ${ }^{53}$ However, in so doing the state may have misunderstood the point of contention. The AMP proposal simply rejected the conflation of the ethnic and religious identity that had so far governed the state's administration of Malay and Muslim affairs.

For the People's Action Party (PAP) government, leadership and representation are based on ethnicity and not religious affiliation. We see this clearly in the formula for the super-constituencies instituted in Singapore's political system in 
the 1990s. The Group Representation Constituencies (GRCs) were introduced to ensure minority representation in parliament. In a GRC, six candidates - one of which must be from a minority group - run on a single party slate to represent a super-constituency. The minority representation, however, is defined narrowly as minority 'race'. For instance, in ascertaining whether a non-Chinese candidate can stand on a GRC slate, the Elections Commission checks the ethnic/racial identity of the candidate - but not his or her religious affiliation.

In the case of representation of the Muslim community, the PAP government assumes that religious representation is encapsulated by the ethnic identity that is by 'Malay' representation. It assumes the Malay Members of Parliament to also be Muslim MPs. Further testimony to this comes from the recent tradition of appointing the Malay cabinet minister - often the Minister of Community Development and Sports - to the position of Minister in charge of Muslim Affairs.

The AMP proposal suggested the need for a separation of ethnic and religious representation. While acknowledging the good that the Malay political leadership had done, the proposal questioned the extent to which the Malay elite truly represented the religious interests of the community. The AMP proposal suggested an acknowledgement of a Muslim elite that could serve as a real bridge between the state and the Muslim society in Singapore. AMP had the 'ulamā' in mind although which particular group of 'ulama ' was not made clear in the proposal. Hence the AMP proposal called for special attention to be paid to the positive role that mosque leaders and 'ulama ' could play at the grassroots level, and in linking the community to the state. They argued that since the 'ulama ' understood the pulse of the religious community best, they should be properly acknowledged as the legitimate alternative Leadership for the Muslim (and Malay) community.

The proposal died a quick death but it does point us to an important tension that results from the growing plurality among Muslims in Singapore and the diminishing space resulting from the state administration of Islam. The colonial period had paved the way for a select Muslim elite to administer Islam. In the post-independence period, the state established MUIS as a kind of religious bureaucracy that could advise it on matters pertaining to Islam. This religious bureaucracy is in the hands of the Malay politicians and not in those of the 'ulamā', leading to questions over who should best represent the Muslim community in their negotiations with the state. However, horizontal contestations of meanings and representations within the community have been growing and questions over who would legitimately represent religious authority vis-à-vis the state have become more difficult to resolve.

Debates over the proposed amendments to the Administration of Muslim Law (AMLA) Act in the late 1990s also testify to this emerging tension between the 'ulam $\bar{a}$ ' and the existing Malay political elite. In 1995, a review of AMLA was carried out by a select committee comprised of officials from MUIS and Muslim 
professionals. No 'ulama $\bar{a}$ ' were specifically consulted. MUIS officials explained that involving the 'ulam $\bar{a}$ ' at that stage was not necessary since many within MUIS were also Islamic scholars. ${ }^{54}$ MUIS met with several Islamic organisations including PERGAS to discuss the proposed amendments to AMLA. PERGAS objected to amendments to the concurrent jurisdiction of the shari ${ }^{\prime} a h$ and civil courts, which would have allowed Muslims the choice of seeking remedy on ancillary matters such as custody, maintenance claims and division of matrimonial property to either court. PERGAS interpreted these moves as undermining the jurisdiction of the shari $\bar{i}^{\prime}$ h court. ${ }^{55}$ The exchanges between PERGAS and MUIS representatives proved heated. The amendments to AMLA were finally enacted in 1998 without incorporating PERGAS's objections. The committee explained that Singapore citizens had to be accorded the right of equal access to civil courts in the event of an irreconcilable dispute at the sharì ah court.

\section{Islam, State, Society and Politics in Singapore: Some Conclusions and Recommendations}

We have tried to show how Islamic society in Singapore is an evolving entity. While there has been substantial fusion of localised Malay identities and Islamic consciousness, the society remains open to external influences and ideational flows creating dynamic shifts within the Muslim community. Hence, Islamic society in Singapore has not only evolved through different phases but also become increasingly more pluralistic and complex. The relationship between state and the society can be characterised by attempts at centralisation of religious authority and careful administration. The incongruence of growing pluralisms within the society and a centralising tendency of the state is producing new arenas of contestation, leading to tensions between the state-sanctioned Muslim elite and the 'ulama' ' community, who are themselves becoming more diverse. Muslim politics in Singapore can therefore be characterised by the horizontal contestations of meanings and a vertical contest for legitimate representation of the Islamic society to the state. To put it another way, emerging tensions between the state and Islam may not be about the infringement of religious rights of a minority Muslim community or about a marginalised Malay community, but as a consequence of the growing complexities within Muslim society itself. Therefore,

- the question for the future is whether the state should allow a new set of Muslim elites to emerge. A second question would be which 'Muslim' elite. For example, not every Muslim agrees with PERGAS's brand of Islam. The tone it has taken in stepping forward as the defender of the religion suggests an intolerant attitude to reformist elements within Islam. For example, on 
the issue of the Muslim headscarf, PERGAS insisted that any ruling on the matter could only be undertaken by "those qualified in the field so as to avoid confusing the masses".

- Muslim politics in Singapore requires a careful balance between the administration of Islam and allowing space for Islamic society to reform itself from within. This may entail less centralisation and more space for greater pluralism within Islam. In the aftermath of the September 11 terrorist attacks in the United States and the arrest of 34 Singaporean Muslim men for allegedly planning terrorist attacks in Singapore in 2001, this careful balance may have become much harder to achieve.

\section{Notes}

1. "Singapore School Dress Code Alienates Muslims", The New York Times, 27 February 2002.

2. Ibid.

3. The Straits Times [Singapore], 3 February 2002.

4. See the official website for KARAMAH, available online at http://www.karamah.org (accessed on 6 July 2010).

5. Singapore Department of Statistics, Ministry of Trade and Industry, "Census of Population 2000", available online at http://www.singstat.gov.sg/pubn/popn/cop2000admin.pdf (accessed on 6 July 2010), 9.

6. Willard Hanna, The Malays of Singapore (New York: American Universities Field Staff, 1966); Stanley Bedlington, The Singapore Malay Community: The Politics of State Integration (Ithaca NY: Cornell University Press Southeast Asia Program, 1974); Tania Li, Malays in Singapore: Culture, Economy and Ideology (Singapore: Oxford University Press, 1989); Lily Zubaidah Rahim, The Singapore Dilemma: The Political and Educational Marginality of the Malay Community (Singapore: Oxford University Press, 1998).

7. Suzaina Kadir and Yusaku Horiuchi, "Political Culture and the Singapore Puzzle", IOC Discussion Papers 8 (Tokyo: University of Tokyo, Institute of Oriental Culture, March 2003), 6-7.

8. Yayasan Mendaki, "Progress of the Malay Community Since 1990", available online at http://www. mendaki.org.sg/content.jsp?cont_cat_id=12\&cont_id=92.

9. Rahim, The Singapore Dilemma.

10. For example, data released by MENDAKI charted the progress of Malays admitted to polytechnics and universities from 1980 onwards. In 1980, only 1.3 per cent of the Malays gained admission to polytechnics and universities, while in 1990 this figure had risen to 13 per cent.

11. William Roff, The Origins of Malay Nationalism (New Haven CT: Yale University Press, 1967); M.B. Hooker, Islamic Law in Southeast Asia (Singapore: Oxford University Press, 1984).

12. Roff, Origins.

13. Sharon Siddique, "Administration of Islam in Singapore", in: Taufik Abdullah and Sharon Siddique (eds), Islam and Society in Southeast Asia (Singapore: Institute of Southeast Asian Studies, 1986).

14. Ibid., 318-19.

15. Roff, Origins.

16. Siddique, "Administration", 324-5.

17. Roff, Origins.

18. Hussin Mutalib, "Islamic Revivalism in ASEAN States: Political Implications", Asian Survey 30, no. 9 (September 1990), 878.

19. Ibid.; Mak-Lau Fong, Modeling Islamization in Southeast Asia: Brunel and Singapore (Taipei: Program for Southeast Asian Studies, 2000). 
20. Fong, Modeling.

21. Kadir and Horiuchi, "Political Culture".

22. Dale Eickelman and James Piscatori, Muslim Politics (Princeton: Princeton University Press, 1996).

23. Hussin Mutalib, "Islamic Education in Singapore: Present Trends and Challenges for the Future", Journal of Muslim Minority Affairs 16, no. 2 (1996).

24. Interview with Ustaz Murad, President of PERGAS, Singapore, 23 February 2004.

25. Muhammad Haniff Hassan, "Asatizah: Siapa dan Bagaimana", At-Takwin [Singapore] (July-September 2001), 11-28.

26. Ibid.

27. Interview with Ustaz Hasbi, President of PERGAS, Singapore, 23 February 2004.

28. Discussion with Mr Alami Musa, President of MUIS, Singapore, 17 April 2004.

29. Interview with Mr Alami Musa, President of MUIS, Singapore, 26 June 2004.

30. Eickelman and Piscatori, Muslim Politics.

31. Siddique, "Administration", 327.

32. Interview with Haji Maarof Salleh, former president of MUIS and research fellow at the Institute of Southeast Asian Studies (ISEAS), Singapore, 21 April 2004.

33. Interview with Haji Maarof Salleh, former president of MUIS, Singapore, 21 April 2004.

34. Siddique, "Administration", 326.

35. Interview with Mohd. Razak Lazim, Director, Mosque Division, MUIS, Singapore, 15 January 2004.

36. The Straits Times [Singapore], 23 August 1999.

37. Interview with Mr Razak Mohammed Lazim, Director, Mosque Division, MUIS.

38. Ministry of Home Affairs [Singapore], "White Paper: The Jemaah Islamiyah Arrests and the Threat of Terrorism", January 2003, available online at http://www.mha.gov.sg/publication_details. aspx?pageid $=35 \&$ cid $=354$ (accessed on 6 July 2010).

39. Ibid.

40. PERGAS press release on Jemaah Islamiyah arrests; see PERGAS website, available online at http://www.pergas.com.sg (accessed on 6 July 2010).

41. They are Madrasah Aljunied, Madrasah Alsagoff, Madrasah Wak Tanjung, Madrasah Al-Maarif, Madrasah AlErsyad and Madrasah Al-Arabiah.

42. See PERGAS press statement in Berita Harian [Singapore; in Malay], 10 May 2000; The Straits Times [Singapore], 11 May 2000.

43. Interviews with Ustaz Zul, Ustaz Murad and Ustaz Hasbi, PERGAS, Singapore, 15 October 2003.

44. See Straits Times Interactive Forum, 11 May 2000, available online at http://www.straitstimes.com/ $\mathrm{ST}+$ Forum/ST+Forum.html (accessed on 6 July 2010).

45. Interviews with Ustaz Murad, Singapore, 17 March 2004; Razak Lazim, MUIS, 25 May 2004.

46. See BBC Online, "Mufti Puts Schools over Scarves", 6 February 2002, available online at http:// news.bbc.co.uk/2/hi/world/asia-pacific/1804470.stm (accessed on 6 July 2010).

47. See PERGAS press releases at the PERGAS website, available online at http://www.pergas.org.sg (accessed on 6 July 2010).

48. Discussion with Mr Alami Musa, President of MUIS, Singapore, 26 June 2004.

49. Berita Harian [Singapore; in Malay], 14 September 2003.

50. Berita Harian Forum [Singapore; in Malay], "Pergas tidak seru masyarakat Islam bersifat secular", 16 September 2003.

51. Discussion with Ustaz Hasbi, 23 February 2004.

52. "Vision 2010: Setting the Community Agenda in 21st-Century Singapore", 2nd National Convention of Singapore Malay-Muslim Professionals, 4-5 November, Singapore.

53. The Straits Times [Singapore], 10 November 2000.

54. Discussion with Haji Maarof Salleh, former president of MUIS, Singapore, 27 March 2004.

55. Report of the Select Committee on the Administration of Muslim Law (Amendment) Bill, Singapore, 1999. 